\section{Abstract}

\title{
A New Stakeholder Opinion-based Rapid Sustainability Assessment Method (RSAM) for Existing Residential Buildings
}

In many developing countries, several strategies and programs have been established to support the green building initiative, but overall progress is too slow to keep up with the global advances.

To accelerate progress in building sustainability as well as to aid the decision-making process of different parties involved, a tailored quantification method for the sustainability performance of buildings is needed. The study presents a Rapid Sustainability Assessment Method (RSAM) - a fast and easy-to-implement system developed using indicators and their respective weights obtained from stakeholders and an assessment approach based on residents' responses. It was then applied to measure the sustainability performance of several residential buildings (from eras: before 1991, from 1991-1998, and after 1998) in the capital of Kazakhstan's, Nur-Sultan (formerly Astana). Results differentiated well between the buildings of different era, revealing that even new buildings certified via international green building rating systems do not entirely satisfy the vision of sustainability of the capital's residents. Although the resident's opinion-based method was developed for existing residential buildings, it is flexible enough to accommodate future changes e.g. including data obtained from other stakeholders (e.g. building management) and assessing non-residential buildings. RSAM is further applicable to residential buildings constructed after 1950s in other similar regions including post-Soviet and Eastern Bloc countries.

Keywords: Central Asia; developing countries; green building; householder opinion; Kazakhstan; sustainability assessment tools; sustainability ranking; sustainability rating 


\section{Introduction}

The increasing number of environmental disasters between 1950s and 1970s has raised public

27 concerns about the environmental impact of anthropogenic activities. This forced governments to take action and, as a result, they pushed for sustainable development initiatives in various areas including construction which accounts globally for 34\% of energy use (IIASA 2012), 19\% of greenhouse gas emissions (IPCC 2014), and along with the demolition of buildings 36\% of waste production (UNEP 2015). After first attempts to build sustainably, it was clear that some sort of measurement is required to evaluate the level of success in achieving sustainability goals. An ability to quantify the sustainability performance of given structures aids the decision-making process and limits arbitrary choices on the path to achieve a desired level of sustainability (AlWaer et al. 2008, Yudelson 2008). The best method for assessing the sustainability level of different structures, including buildings, is to use sustainability rating systems (Haapio and Viitaniemi 2008). There are currently numerous sustainability assessment tools developed worldwide to address this challenge, and a review of some of these methods is provided in the following section. In Kazakhstan, several strategies, concepts, and memorandums aim to support the sustainability and these initiatives have also led to the establishment of Kazakhstan's Green Building Council

41 (KazGBC) - a member of World Global Building Council (WGBC). KazGBC, in cooperation with 42 the United Nations Development Programme (UNDP), aims to introduce green construction 43 standards and to motivate construction companies to certify buildings under BREEAM and LEED 44 systems. Although the number of certified buildings is growing, the certification rate is too low to meet the 2030 target set by KazGBC (ITE Build \& Interiors 2016). The progress by the green 46 building initiative in Kazakhstan is relatively low due to following reasons: inadequate 
47 consideration given to green building principles by the outdated construction standards and

48 regulations, a limited participation among construction industry members in green projects mostly

49 due to their overall higher cost, and insufficient academic and research background on the

50 sustainable buildings in the context of Kazakhstan. These root causes of overall poor sustainability

51 practices, among others, are related to a lack of respective policies and regulations, guidelines,

52 methodologies, practical examples, and technologies as well as low levels of awareness among the

53 general public and the construction industry (UNDP 2013). Moreover, all certified buildings have

54 only been constructed within the last decade which comprises only a small portion of the whole

55 building stock in the country, whereas the sustainability of the existing buildings remains

56 unassessed. In order to have a better understanding of the situation regarding these buildings, there

57 is a need to develop a quick and effective sustainability assessment method tailored to

58 Kazakhstan's context which would be used for numerous types of buildings while at the same time

59 without inquiring large resources.

60 Including the stakeholders in the development process of an assessment methodology is key for

61 achieving solutions that are environmentally, functionally, aesthetically, and economically viable

62 for all involved (Bal et al. 2013, Stephan and Menassa 2015). In general, the stakeholders are

63 defined as people who have interests in, can influence, or be influenced by a company or

64 organization (Freeman 1984, Freeman et al. 2007, Freeman et al. 2010). A few studies assert the

65 importance of stakeholders' engagement in construction (Mathur et al. 2008, Bal et al. 2013,

66 Herazo and Lizarralde 2016). In particular, Mathur et al. (2008) pointed out three distinct

67 approaches for conceptualizing stakeholder engagement in construction projects which relate to

68 viewing stakeholder engagement as a management technique, an ethical requirement, or a forum

69 for dialogue to facilitate mutual social learning. The benefits of using all these methods are clear 
and the opinions of stakeholders are critical in the proper assessment and analysis of requirements

71 (Bryson 2004, Boecker et al. 2009, Gan et al. 2015). The involvement of multiple stakeholders

72 plays a pivotal role in achieving sustainability goals.

73 The sustainability of buildings in Central Asia and in particular in Kazakhstan has yet to be studied

74 in detail. To the authors' knowledge, the only published work on the subject covering the

75 construction sector in Kazakhstan has been recently performed by Akhanova et al. (2020). The

76 authors developed a Kazakhstan's Building Sustainability Assessment Framework (KBSAF) using

77 the stepwise weight assessment ratio analysis (SWARA) technique for estimating weights of the

78 system's categories and indicators, however; the framework focuses on assessing the sustainability

79 performance of commercial buildings only, including office and retail buildings. Furthermore, the

80 system involves a total number of 200 items to assess and requires extensive data collection for

81 proper sustainability assessment, which the authors strive to achieve through BIM technologies.

82 The method of data acquisitions along with the focus on the assessment of commercial buildings

83 creates an approach to the evaluation of buildings' sustainability that is completely different from

84 the one discussed in the present paper.

85 The present research aims to develop a systematic approach using stakeholders' perceptions and 86 opinions for evaluating building sustainability: Rapid Sustainability Assessment Method (RSAM).

87 It then specifically aims to obtain a snapshot of the current level of sustainability of existing residential buildings in Nur-Sultan (formerly Astana), Kazakhstan by the application of RSAM to

89 selected buildings. RSAM can also be used for the assessment of buildings erected in the second 90 half of the $20^{\text {th }}$ century in other contexts directly (e.g. cities of post-Soviet and Eastern Bloc

91 countries with very similar building characteristics and construction practices) as well as indirectly

92 following minor modifications (e.g. cities of other developing countries). 


\subsection{Review of existing sustainability assessment methods}

96 In the past, various sustainability tools with distinct goals and scopes have been introduced. These

97 include environmental impact assessment (focusing on the impact of a project based on its

98 localization on various modules of environment e.g. fauna, flora, communities, etc.), life cycle assessment/analysis (overall impact of a product over its lifetime), total quality assessment

100 (focusing on all pillars of sustainability i.e. environmental, economic, and social), cumulative energy demand (focusing on energy consumption), and building assessment tools which is the

102 focus of the following discussion. According to Reijnders and van Roekel (1999), the assessment

103 tools can be roughly classified as either qualitative tools (that are based on criteria and scoring)

104 and quantitative ones (which use life-cycle approach and quantitative input and output data of 105 matter and energy flows). Two of the most commonly used qualitative tools are BREEAM 106 (Building Research Establishment Environmental Assessment Method) and LEED (Leadership in 107 Energy and Environmental Design), whereas tools based on life-cycle assessment (LCA) approach 108 include EcoEffect, EcoQuantum, Environmental Load Profile (ELP), BEES (Building for 109 Environmental and Economic Sustainability), BEAT (Building Environmental Assessment Tool, 110 Denmark), and ITACA (Forsberg and von Malmborg 2004, Asdrubali et al. 2015). A similar 111 classification as provided by Ali and Al Nsairat (2009) that classifies existing building assessment 112 methods as either life-cycle assessment-based or multicriteria-based. The most notable multi113 criteria rating systems that acquired worldwide recognition in the last decades include but are not 114 limited to BREEAM (UK), LEED (USA), CASBEE (Comprehensive Assessment System for Built 
115 Environment Efficiency, Japan), and Green Star (Australia, New Zealand, South Africa) (Zhang

116 et al. 2017).

117 In BREEAM, the overall sustainability score of the building is calculated by evaluating the number

118 of credits for each of its ten categories, multiplying them by weighting factor based on the

119 category's importance, and summing them up (Gou and Xie 2017). LEED, on the contrary, awards

120 points in its nine categories based on the number of requirements satisfied which are then added

121 up to 110 total points (Castro-Lacouture et al. 2009). Green Star has adopted many of the features

122 presented in LEED but has adjusted them to the regional context. CASBEE utilizes a completely

123 different approach to score calculation: the system evaluates the building's sustainability

124 performance using "Building Environmental Efficiency (BEE)" which is a ratio of "Building

125 Environmental Quality and Performance (Q)" to "Building Environmental Loadings (LR)"

126 (Banani et al. 2013). All of these sustainability assessment tools consider the building's various

127 stages including its design, construction, and operation where CASBEE further investigates the 128 deconstruction phase of the building's lifecycle.

129 Due to differing approaches these methods utilize, the same building might be given different 130 performance scores depending on the rating system used. To address this issue, Asdrubali et al. 131 (2015) proposed a methodology to normalize the overall sustainability performance scores which 132 they apply to two buildings in Central Italy evaluated using LEED and ITACA, respectively. They 133 identified the differences between the methods, established key categories (or "macro-areas") (site, 134 water, energy, indoor environment quality, and materials) based on common indicators, reassigned 135 new scores based on the new macro-areas, and compare the resultant values. A similar approach 136 has been employed in the present study: a simplified normalization procedure of the four rating 137 systems was performed to compare their agendas in sustainability performance evaluation (Figure 
1) (JSBC 2005, GBCA 2009, USGBC 2009, BRE 2011). The present study established five key categories ("sustainable sites", "energy", "water", "materials and resources", and "indoor environment quality (IEQ)") common to all of the examined sustainability assessment methods and the importance of each key category was determined in percentages. All discussed rating systems have distributed some credits outside of the identified key categories, but, for the sake of comparison, the credits attributed to these five key categories were assumed to comprise $100 \%$ of the total score.

Although the sustainability assessment tools selected for the present discussion share a consensus on their basic structures, the approach to achieving sustainability goals in these categories that each rating system demonstrates is unique. For example, LEED and Green Star consider the key category as "energy", awarding the highest amount of points $-40 \%$ and $33.3 \%$, respectively. CASBEE, on the other hand, awards an equal amount of credits $(28.5 \%)$ to both "energy" and "IEQ", the former being the most essential category within "LR" and the latter being the lead key category of "Q". Meanwhile, BREEAM chooses "materials and resources" category as the most essential one allocating $29.5 \%$ of the credits to this key category and only $22.5 \%$ to "energy" category. An agreement is observed between LEED, BREEAM, and Green Star for "IEQ" category as they award 19-21.3\% of credits to this category, which is considerably less compared to CASBEE. The least significant key category in all rating systems is "water" category: Green Star $-13.3 \%$, LEED - 13\%, BREEAM - 10\%, and CASBEE awarding the least number of points $-3 \%$. There is also a discrepancy amidst the methods on how they approach "sustainable sites" category: whilst CASBEE awards as high as $21.5 \%$ in this category, LEED restricts the number of achievable credits to $12 \%$ of the maximum score. The basis of these four sustainability assessment tools is built upon the discussed five key categories, but the differences in importance levels these 
161 methods allocate to the key categories, not to mention the indicators left outside of the comparative

162 (sensitivity) analysis, demonstrate a general lack of agreement on how the global building sector 163 should approach sustainability.

164 Banani et al. (2013) performed a comparative analysis of five different SA tools including 165 BREEAM, LEED, Green Star, and CASBEE; which shed a light on how the tools assess important 166 indicators falling outside of the scope of five key categories. All four tools recognize the 167 contribution of buildings to the global pollution problem; but BREEAM, Green Star, and CASBEE 168 assess pollution as an individual category whereas LEED distributes restrictions to emissions 169 across several other categories. In addition, BREEAM and Green Star consider management as 170 well as transportation as separate categories whereas LEED and CASBEE choose to distribute 171 these parameters across different assessment categories. Moreover, BREEAM, LEED, and Green 172 Star reward innovative approaches in achieving sustainability goals, whereas CASBEE does not 173 include this criterion in evaluation, instead choosing to consider region-specific parameters such 174 as "earthquake resistance" and "restriction of wind damage". This comparative analysis along with 175 the differences between the key categories addressed here show that the discussed methods have 176 a common perspective on components of sustainable building but approach the evaluation process 177 in different fashions best fitting their country of origin.

178 Issues with the applicability of global sustainability assessment methods to certain regions has led 179 to numerous studies attempting to adapt international tools such as LEED and BREEAM to 180 country-specific conditions and to propose their own model for sustainability assessment. Ali and 181 Al Nsairat (2009) developed a green building assessment tool for residential buildings in Jordan 182 tailored to various domestic regions considering variances in climate and geography within the 183 country. Al-Jebouri et al. (2017) proposed a sustainability assessment system which can be further 
184 customized for different types of buildings in Oman by reviewing existing international and 185 regional sustainability rating systems, identifying categories and indicators distributed among five 186 pillars of sustainability (environmental, economic, social, cultural, and governance), and 187 evaluating their relative weights. They claim that Middle Eastern countries (UAE in particular) 188 admit the importance of regional context and culture in achieving sustainability and therefore 189 regard them as a fourth pillar and include these in their sustainability-rating systems known as 190 UAE Estidama. Following the example of UAE in developing their own domestic system, Banani 191 et al. (2016) compared five major green building assessment tools to establish a framework for 192 sustainability assessment of non-residential buildings, despite the adoption of the U.S. LEED 193 sustainability rating system by the Saudi Green Building Council as its official tool for 194 sustainability performance evaluation. They claimed that, at that moment, the country lacked 195 specific assessment methods that would address the unique economic, social, and cultural aspects 196 of Saudi Arabia. Mahmoud et al. (2019) addressed the issue of the inapplicability of contemporary 197 methods outside of their country of origin and developed a sustainability assessment tool for 198 existing buildings with a weighting system based on Fuzzy Hierarchal Process Method that can be 199 used globally while demonstrating how regional variations affect the sustainability assessment 200 process. These studies acknowledge and confirm the need for substantial effort arising whenever 201 a sustainability rating tool is adapted to the country-specific conditions.

202 Although existing buildings provide multiple challenges regarding urban sustainability, the 203 sustainability assessment tools designed for them are limited. Amidst all phases of the building's 204 lifecycle (i.e. raw materials extraction and processing, production of construction materials, 205 construction of the building, operation, maintenance, and demolition), the operation and 206 maintenance stage (involving: electricity use in the outlets, HVAC and lighting, heat in ventilation 
and conduction, materials in internal surfaces and HVAC services, and the use of water and wastewater) accounts for 45-75\% of the total environmental impact (Seppo 2004). This underlines the importance of evaluating the sustainability level of existing buildings and suggesting a way to reduce their adverse impact on the pillars of sustainability.

As there are numerous sustainability assessment tools for building sustainability assessment, there are also some rating systems focusing specifically on the evaluation of existing buildings. Two important examples of these commercial tools are "LEED for Existing Buildings: Operations and Maintenance (LEED-EBOM)" (USGBC 2014) and "Green Star South Africa - Existing Building Performance (SA EBP)" (GBCSA 2014). The scope of LEED-EBOM involves the certification of sustainability levels of ongoing operations at existing institutional buildings, including offices, retail and service establishments, institutional buildings, hotels, and residential buildings of four or more habitable stories. It aims to provide the individual rating of a whole building, whether owner-occupied, multi-tenant, or multiple-building campus projects. Moreover, the rating system encourages the implementation of sustainable practices and reduction in the environmental impacts of existing buildings over their functional life cycles. It addresses exterior building site maintenance programs, water and energy use, environmentally preferred products and practices for cleaning and alterations, sustainable purchasing policies, waste stream management, and ongoing indoor environmental quality. There is a slight variation between weighting systems of LEED-EBOM and LEED for New Construction: e.g. the former accounts for solid waste management but the latter does not. This leads to differing environmental footprints addressed by each rating system (USGBC 2014).

Green Star SA EBP was developed based on the Green Star system proposed by the Green Building Council of Australia by tailoring its sustainability assessment criteria relevant to the South African 
230 context. It covers the same environmental categories addressed in the Green Star: new building

231 tools which are management, indoor environment quality, energy, transport, water, materials, land

232 use and ecology, emissions, and innovation. However, the focus is on the operations and

233 management stage of the building's lifecycle to optimize its performance. The scope of the rating

234 system spans from commercial buildings including office buildings, retail buildings, public

235 assembly buildings, and low-risk industrial buildings to institutional and multi-unit residential

236 buildings; addressing effectively relationships between buildings' landlords and tenants (GBCSA

237 2014).

238 Since the proposed LEED-EBOM and Green Star SA EBP both focus on the existing structures

239 only, they share a relatively similar structure except for differences mainly due to the regional

240 context (Table 1). Both sustainability assessment tools recognize the importance of the efficient

241 use of energy and allocate a large weighting to this key category correspondingly. However,

242 LEED-EBOM promotes the use of both on-site and off-site renewable energy sources which is

243 completely overlooked by Green Star SA EBP. Another striking difference between the methods

244 is that Green Star SA EBP treats transportation, emissions, and management as separate categories

245 whereas LEED-EBOM distributes these parameters among other categories. There is a

246 considerable similarity in how these tools evaluate IEQ category: they award almost equal amounts

247 of credits to this category which assesses indoor air quality, lighting, acoustic and thermal comfort,

248 daylight, and views. Both methods also promote building-scale metering and monitoring,

249 sustainable land use, landfill diversion, efficient water use, control of refrigerants leaking, green

250 cleaning practices, green procurement and purchasing, as well as innovations in sustainable

251 solutions. They also give more credits to the existing building that has been certified with their

252 ratings before and has accredited professionals consulting the owner or the building's management 
253 team. In summary, LEED-EBOM and Green Star SA EBP share more similarities than differences

254 in evaluation of existing structures' sustainability performance.

\section{$256 \quad 1.3$ Identified gaps of current sustainability rating tools}

258 The sustainability assessment methods discussed above as well as other established rating systems 259 share some common implementation issues. One of the major drawbacks of the tools is the 260 complexity of their structure resulting from attempts to make the assessment framework as 261 comprehensive as possible. The current state of many sustainability assessment methods requires 262 a substantial amount of data and time, and any attempt to simplify procedures may result in the 263 consideration of less indicators important for overall sustainability rating (Taisch et al. 2013, 264 Alhumaidi 2016).

265 Another limitation of the existing methods is that most of them have a unique set of objectives or 266 a certain niche they were designed for forcing their users to utilize a combination of different 267 methods for a complete sustainability assessment of one project (Taisch et al. 2013). Moreover, 268 the absence of a commonly agreed scientific way to develop a weighting system for criteria of 269 varying significance leaves space for subjectivity and, therefore, possible misinterpretation of the 270 actual sustainability level of the building (Alhumaidi 2016).

271 Due to global variations in geography, climate, economics, history, culture, and government 272 regulations, tailored sustainability assessment tools have been generated for a number of countries 273 (e.g. Asdrubali et al. 2015, Kridlova Burdova and Vilcekova 2015, Banani et al. 2016), since the 274 assessment methods developed for one country/region may not be fully applicable to others (Cole 275 1999, Darus et al. 2009, Banani et al. 2013, Alhumaidi 2016). Contemporary sustainability 
assessment tools vary in aspects of their assessment models including indicators and weighting

277 systems due to unique regional context involving climate and geographical features, level of

278 development, priorities established by the governments, public awareness etc. (Banani et al. 2013).

279 The origin of a specific tool determines the importance of different aspects of sustainability, and therefore, their inclusion in the assessment criteria (Todd and Geissler 1999). Moreover, the lack

281 of consensus on how to calculate weights for each indicator and the subsequent emergence of 282 different approaches to developing weighting systems also defined by the country of origin 283 contributes to a globally inapplicability of these tools (Ding 2008). Mateus and Bragança (2011) 284 state that the global tools require prior adaptation which needs time. These inconsistencies among 285 the established sustainability tools lead to sophisticated and, thus, time-consuming and resource286 intensive process of their adaptation to the regions outside of their origin.

287 In building sustainability assessment tools, occupants' involvement in assessments is either not 288 considered at all or is optional accompanied by a minor weight in the overall assessment score. 289 However, the opinions of residents can be used to provide a valuable basis that reflects the 290 sustainability level of existing buildings. Residents living in a building are in a particularly good 291 position to effectively evaluate different aspects of that building's performance as they spend the 292 highest amount of time there and have a great interest in improving their experience and comfort 293 levels. For example, Green Star SA EBP has an indicator called "occupant comfort survey" which 294 facilitates the inclusion of householders in the sustainability assessment of the building they 295 occupy and gives an insight of overall comfort levels. The survey is basically a 7-point scale 296 questionnaire that assesses the respondent's satisfaction with acoustic comfort, thermal comfort, 297 lighting, indoor air quality and ventilation, and building management (cleanliness, odors, etc.). 298 However, conducting occupant surveys is not mandatory and is awarded only up to two points out 
299 of 110; based on population coverage, occupants' satisfaction level, improvement compared to 300 previous survey (if applicable), and development of correction plan (GBCSA 2014).

301 A similar survey is a part of LEED-EBOM rating system, however; the tool only awards one point 302 out of 110 if a survey is conducted covering at least $30 \%$ of the building's occupants; assessing 303 the occupants' comfort including aspects such as thermal comfort, acoustics, indoor air quality, 304 lighting levels, and building cleanliness. The tool requires, though, developing corrective actions 305 306 however, this is optional and at an insignificant level.

The present research aims to develop a new sustainability rating system, RSAM, using stakeholders' perceptions and opinions for evaluating buildings. The rating tool uses the opinions of residents identified through questionnaires tailored to their level of knowledge of the building 311 and expertise in sustainability providing rapid, low-cost, and dependable data to assess the 312 building's sustainability performance. Although such a method might lack some of the 313 comprehensiveness of existing and yet time-consuming and resource-intensive methods, it 314 prioritizes the occupants' perspectives on the sustainability performance of the building with 315 which they are quite familiar. It then specifically aims to obtain a snapshot of the current level of 316 sustainability of existing residential buildings in Nur-Sultan, Kazakhstan by the application of 317 RSAM to selected buildings. RSAM can also be directly used for assessment of buildings erected 318 in the second half of the $20^{\text {th }}$ century in other contexts (e.g. in cities of post-Soviet and Eastern 319 Bloc countries with very similar building characteristics and construction practices) as well as 320 indirectly following minor modifications (e.g. in cities of other developing countries). 
324 The RSAM method covers three pillars of sustainability (environmental, economic, social and

325 functional) employing several assessment parameters hierarchically subcategorized into factors,

326 then to indicators, and finally to sub-indicators. It measures stakeholder opinions on the existing

327 applications of the building's structural elements and provided service systems. Specific weights

328 have been assigned to calculate scores with a bottom-up approach based on the judgments of

329 stakeholders. The model along with the indicator weights can be easily modified as a basis for

330 evaluating buildings in other contexts. A graphical summary of the proposed method is given in

331 Figure 2 and a detailed method (MethodsX) file is provided.

332 The three factors covered by RSAM are represented by the abbreviations: ENV - Environmental

333 factor, S\&F - Social and Functional factor, and ECO - Economic factor. Subsequently, indicators

334 and sub-indicators of any factor are presented as level numbers following the corresponding factor 335 abbreviation, e.g. ENV4.3, ECO2.1, or S\&F3.2 (Table 3).

\subsection{Identification of factors and indicators}

339 The indicator selection stage has been completed via activities falling into two domains: people 340 and knowledge resources (Figure 2). Information from stakeholders (people) and research 341 (literature review) were utilized. Stakeholders $(n=68)$ between 19 and 57 years old from the 342 following groups (Table 2) have been interviewed: "Public" (with a relevant engineering 343 background, graduate degree (PG) and undergraduate degree or with high-school degree (PU)), 344 "Academy" (sustainability expert academicians (AC)), and "Construction industry" (office 
345 workers $(\mathrm{CO})$ and field workers $(\mathrm{CF})$ ). As a result, a total 12 indicators and 39 sub-indicators have 346 been identified (Table 3).

\section{$348 \quad 2.2$ Quantification of priorities and weights}

Weights were collected from stakeholders via interviews and surveys. Likert rating scale (1-5) (i.e. “not important at all" (1), "not important" (2), "neutral” (3), "important" (4), and "very important" (5)) was used. The average values of all responses were calculated and used in the model as score multipliers (weights) (Table 3). After collecting the weights, a three-step statistical approach was conducted for further evaluation via SPSS 25.0 software. Firstly, the reliability of the considered

355 data was tested using Cronbach's Alpha test. It is a common measure of the internal consistency

356 of a set of items in a survey to gauge its reliability (Cronbach 1951, George and Mallery 2003). If

357 Cronbach's alpha is as low as $0.50-0.60$, then the data set is appropriate only for exploratory 358 research, while 0.70 is generally perceived as well acceptable (Nunnally 1967, Hair et al. 2010). 359 The result confirmed that the survey outputs are reliable.

360 Shapiro-Wilk normality test was used to identify the nature of the collected data ( $\mathrm{p}<.05$ for all 361 stakeholder opinions on 51 indicators (Table 4)). It showed that the collected data can be analyzed 362 using non-parametric statistical techniques. Kruskal-Wallis test is a non-parametric test, and its 363 dependency on fewer assumptions leads to more reliable results (Reimann et al. 2008). It was used 364 for identifying the differences in opinions between various stakeholder groups. Some other similar 365 studies used the Analysis of Variance (ANOVA) for analysis of multiple sample means (e.g. Toor 366 and Ogunlana 2009, Mascarenhas et al. 2014, Heravi et al. 2015). However, since the sample size 
367 of the collected surveys was not very large and the normality of the data was under question, the

368 Kruskal-Wallis test was more appropriate to use for the present study.

369 Finally, ranking using Mean Score Analysis (MS) was used to indicate the overall respondents'

370 perception of the indicators. It is commonly used (e.g. Makuei and Oladapo 2014, Aigbavboa et

371 al. 2017) to assess respondents' understanding of sustainable construction practices and

372 prioritization of all the indicators measured with Likert scales (Ojoko et al. 2018). MS can be 373 calculated as follows:

$374 \quad M S=\frac{5 n_{5}+4 n_{4}+3 n_{3}+2 n_{2}+1 n_{1}}{\left(n_{5}+n_{4}+n_{3}+n_{2}+n_{1}\right)}$

375 Where, $n_{1}$ to $n_{5}$ are the number of respondents who choose the options: 1 ("not important at all"),

3762 ("not important"), 3 ("neutral"), 4 ("important"), 5 ("very important"); respectively.

377

\section{$378 \quad 2.3$ Ten points scaling (TPS) system and RSAM score}

379

RSAM performs a quantitative assessment based on a TPS assessment. The main aim of assigning

381 points in this method was to reveal exact implementations that were better or superior to the 382 average or common applications in the context of the selected city. The measurement for each sub-

383 indicator should support the rapid assessment based on householder opinion i.e. it should not be 384 complicated or highly technical. After reviewing the existing literature along with the feedback 385 from the stakeholders, householder opinion/information-based measurement methods were 386 suggested for all sub-indicators (further details presented in the methods (MethodsX) file).

387 The weighted RSAM scores for objective sets: indicators, factors, and overall, are calculated as:

$$
I_{j}=\frac{\sum_{i=1}^{n} W_{i} \times S I_{i}}{\sum_{i=1}^{n} W_{i}}, F_{k}=\frac{\sum_{j=1}^{m} W_{j} \times I_{j}}{\sum_{i=1}^{m} W_{i}}, S=\frac{\sum_{k=1}^{3} W_{k} \times F_{k}}{\sum_{k=1}^{3} W_{k}}
$$


389 Where $n, m$, and $k$ are the number of sub-indicators, indicators, and factors belonging to those 390 objective sets, respectively; $W_{i, j, k}$ is the related weights; and $I_{j}, F_{k}$, and $S$ are the RSAM scores of 391 the indicators, factors, and overall, which are the weighted averages of all objective sets, 392 respectively. All ratings are between 0 and 10.

\section{Results and Discussion}

\subsection{Stakeholder opinions on sustainability indicators}

The descriptive statistics of all stakeholder groups' perception of the indicators denotes a mean value of 4.22 , variance of 0.11 , and a standard deviation of 0.33 . The analyses showed that the coefficient of variation is not high $(<8 \%)$. The reliability test of the various stakeholder groups'

401 opinions about the presented indicators reveals that the Cronbach's alpha score is 0.84 , which is $402>0.70$ - the threshold value for considering whether data have a good internal consistency 403 (Nunnally 1967; Hair et al. 2010). A further investigation using the Kruskal-Wallis test was 404 performed to find significant differences between stakeholder groups on the indicators. It showed 405 that various groups ( $\mathrm{PG}, \mathrm{PU}, \mathrm{AC}, \mathrm{CO}$, and $\mathrm{CF}$ ) have a significant difference in opinion on 406 sustainability indicators ( $\mathrm{p}<0.05)$ (Table 5), all stakeholder groups' opinions on the considered 407 indicators showed significant differences.

408 In order to elaborate and further discuss the main differences in the stakeholders' opinions, the 409 average weights of the groups for Level 1 parameters ("environmental", "economic", and "social 410 and functional") are illustrated in Figure 3. The economic factor was rated as the second important

411 factor at around 4.5 in all groups except for "field workers", who assigned equal weights (4.6) to 
412 all three factors. Meanwhile, the most and the least important factors vary significantly between

413 the remaining groups. Both "graduate degree holders" and "office workers" gave priority to "social

414 and functional factor", whereas "academy" and "university or high school diploma holders" rated

415 it as the least important factor. A substantial difference in the weights was observed in the opinions

416 of the graduate degree holders against the other groups since they are the only group to rate the

417 environment factor as the least important one (at 4.3). Despite some disagreement among the

418 stakeholder groups on the order of priorities given to Level 1 parameters, the range of the weights

419 of these parameters are slim i.e. spanning only from 4.2 to 4.7 out of 5 , and the stakeholder groups

420 assign them similar significance in the overall assessment.

421 The results of Mean Score Analysis (Table 6) showed that in "environmental" category (ENV),

422 respondents rated both "water" and "energy" indicators as the most important and relevant ones,

423 whereas "soil use and biodiversity" was perceived as the least important. More specifically, "heat

424 loss/insulation" and "water consumption" are considered as the most important sub-indicators by

425 not only the study stakeholder groups but also the residents of Nur-Sultan. This can be explained

426 by harsh winters and relative water scarcity due to extreme continental climate of the region

427 (characterized by long winters and relatively dry summers). Typically, occupants were not

428 satisfied with the drops in room temperature when windows are opened for ventilation purposes.

429 Energy provider companies in Nur-Sultan also highlight decreasing heat losses throughout the city

430 as their operational priority, though Nur-Sultan has significantly lower heat losses (13.6\%)

431 compared to Almaty (20\%), the second major city in Kazakhstan (ESMAP 2018). The local

432 population finds the hardness of the city's tap water too high to drink without any further treatment;

433 therefore, the majority prefers filtered (obtained by installing a filtering device in the apartment)

434 or bottled water (ordered from local suppliers or bought in stores) for drinking purposes (Lee 
435 2016). Filtering tap water is appreciated significantly by "AC" stakeholder group (comprised 436 mostly of citizens of other countries), who uses mainly bottled water for drinking and finds its 437 delivery timing issues problematic.

438 During the evaluation of "economic" category (ECO), which encourages an integrated design 439 process optimizing building performance, the stakeholders of all groups voted for "operational 440 costs" of the building. The main costs which influence "operational costs" and represent 441 sustainability of the building are "energy" and "water consumption" costs. This result (rank 9, 442 Table 6) clearly indicates that the residents are more concerned with the costs on energy and water 443 consumption in Nur-Sultan mainly due to their income levels. Kazakhstan has a developing 444 economy with a GDP recently moved up into the level of middle-income country. Generally, 445 average-income households are able to pay for energy and water, yet low-income population has 446 issues with paying these bills. For this reason, heat tariffs are highly subsidized and thus kept 447 artificially low (at about one-fifth of the actual cost), but the energy and water costs cannot be 448 lowered further without substantial financial support from the state (ESMAP 2018). Although 449 Kazakhstan has initiated water and energy efficiency programs ("Energy Efficiency 2020", 450 "Integrated Water Resources Management and Water Efficiency up to 2025"), the population is 451 still concerned about the costs on consumption of water and energy.

452 Among the stakeholders' ratings, "social and functional" category (S\&F) parameters, "indoor air 453 quality" indicator was considered as the most critical issue for Nur-Sultan's residents since all 454 survey respondents identified this indicator as the highest priority (rank 1, Table 6). As respondents 455 are aware that poor indoor air quality causes numerous health issues, the need for better indoor air 456 quality monitoring to combat health risks and enhance occupants' comfort becomes more apparent.

457 Moreover, it is important to use the right combination of strategies of passive design and active 
measures (e.g. cooling, heating, solar energy, electric ventilation). The survey showed that the population rated "mobility plan" and "passive systems" as the least important indicators, whilst "ventilation" and "temperature" were given $2^{\text {nd }}$ and $4^{\text {th }}$ priority levels after "indoor air quality".

\subsection{Classification and assessments of residential buildings (case studies)}

Nur-Sultan, as the new capital of Kazakhstan since 1998, is a rapidly developing city with the greatest construction output in the country. With a nearly three-fold population growth over the last two decades since the city was appointed as the new capital, Nur-Sultan has previously struggled to provide sufficient housing stock to meet the growing demand. The government has been continuously providing substantial financial support to tackle this issue, which has led to a notable construction boom and has made the construction sector one of the leading industries (Cole 1999, Kridlova Burdova and Vilcekova 2015). At present, the city has a diverse residential building stock ranging from Soviet-era buildings to the ones built after the establishment of the newly independent government in 1991 until 1998, and finally, the new generation buildings built after the Kazakh government appointed Nur-Sultan as the capital city in 1998.

The previous research by the authors has investigated the sustainability level of residential buildings in Kazakhstan and has pointed out that the level of sustainability has a correlation with the building's age and comfort levels (Tokbolat et al. 2018). The study classified residential buildings as (a) "old": panel and brick multistory buildings depending on materials and components used for construction, and houses typical single-standing dwellings; and, (b) "new": buildings built using mainly concrete, different filling materials, and bricks, subcategorized as 'economy, comfort, business, and premium' class buildings based on their comfort level. The latter 
481 category covers nearly two-thirds of the housing needs of the city's population (Tokbolat et al. 482 2018).

483 The present study uses RSAM to assess the sustainability of residential buildings and complexes 484 in Nur-Sultan using a slightly different classification than Tokbolat et al. (2018). The building485 related information about the case studies was gathered mainly from the buildings' residents 486 whereas a small amount of additional data acquired from other stakeholder groups such as building 487 management and construction companies. For example, "old" buildings were classified in two 488 categories: (1) buildings constructed in the period between industrialization in 1950-60s and the 489 dissolution of the Soviet Union in 1991, (2) buildings constructed in the period from the 490 independence of Kazakhstan in 1991 to the appointment of Nur-Sultan as the capital city in 1998. 491 At the same time, "new" buildings were not further categorized based on their comfort levels but 492 were rather considered as one group, since dividing buildings by their comfort level is a 493 predominantly commercial initiative developed by the construction companies for marketing 494 purposes, which may be biased. Therefore, the present study used a third generalized category 495 (3) "new buildings". Categories (1) and (2) had one sample building per category and category (3) 496 included ten buildings selected from various districts of Nur-Sultan. The greater prevalence of new 497 buildings in the samples pool is due to (a) the interest in new buildings as they will be in service 498 longer than the older buildings, (b) their ever increasing share in the city's building portfolio, and 499 (3) a larger availability of data which supports sustainability assessment. Householders' data were 500 collected from a minimum five randomly selected samples per building, and results were reported 501 and discussed based on the average values.

502 The assessment scores of all case studies are summarized in Figure 4 where first two bars present 503 the overall and weighted factor contributions of the "old buildings", while the following three bars 
504 illustrate the lowest, average, and best scores of the "new buildings", respectively. In general, the

505 assessment results have shown that the "Case 1" building (built before 1991) has the lowest

506 sustainability performance score overall as well as in each factor individually. "Case 2" building

507 (built between 1991-1998) presents a rather unexpected and competitive sustainability level 508 compared to some of the more recent structures - "new residential buildings" ("Case 3" and "Case

509 4"), mainly due to its great performance in the economical aspect. Another significant finding of 510 the assessment is that the environmental parameter scores are either low or not satisfactory across

511 all building categories, and yet there seems to be a gradual improvement in the environmental 512 aspect of buildings' sustainability over time. Moreover, to validate the occupants' assessment of 513 the building in "Heat loss/Insulation" sub-category, the authors estimated R-value, the thermal 514 resistance of the wall materials (the greater the R-value - the better the insulating properties of the 515 building), of the case study buildings and compared them to the responses. The findings suggest 516 that there is an as strong correlation between estimated R-values and the assessment of the 517 building's insulation done by occupants. The subsections below present the details of the selected 518 case studies and their assessment results.

\subsubsection{Case 1: residential building built before 1991}

521

522 A typical residential building representative of the structures built before 1991 is selected from a 523 suburban area in Nur-Sultan. The neighborhood where the building is located, including the 524 building itself, was constructed at the end of 1980s (relatively new as a Soviet-era building, and 525 thus comparable to other buildings) in accordance with the construction standards and regulations 526 of the Soviet Union. The neighborhood was initially planned as a 'residential district' consisting 
527 of similar buildings, and now contains two schools, two kindergartens, one clinic, and several 528 grocery and convenience stores. The area has many large trees which enhances the overall image 529 of the neighborhood. Currently, the average price of the apartments of this kind of buildings is 530 relatively low due to unfavorable conditions (e.g. old elevators or none, inconvenient floor plans, 531 smell from basement, old pipes that break often, limited parking space) and the unwillingness of 532 city residents to live in old buildings. The assessed building has four floors with 126 apartments 533 in total. The average monthly energy consumption is $133 \mathrm{kWh}$ per person, which is higher than 534 the average energy consumption by the city's residents (101 kWh per person) (ESMAP 2017). 535 This can be explained by the age of the building, associated losses through the building's envelope 536 (R-value of the external wall components is calculated as $14.7 \mathrm{~W} / \mathrm{m}^{2} \mathrm{~K}$ ), and inefficient household 537 equipment. Nevertheless, the building received a relatively high score of 5.3 in $\mathrm{S} \& \mathrm{~F}$ factor 538 improved by the location of the building in a vibrant and socially comfortable area. The fact that 539 the building is surrounded by rich vegetation and trees native to the region has also contributed 540 positively to the S\&F score. However, results show that ENV score of the building is very low 541 (2.3). The overall RSAM score for the building is 3.9, which corresponds to a low sustainability 542 performance level and can be explained by the age of the building and the poor/non-existing 543 sustainability agenda at the time of its design and construction.

\subsubsection{Case 2: residential building built from 1991 to 1998}

547 A residential building typical to this category was selected among the buildings constructed prior to Nur-Sultan becoming a capital in 1998. The area consists of several dozens of multistory 549 residential buildings built starting from 1997 and located on the embankment of Ishim River. It 
550 also has a wide range of commercial amenities such as convenience stores, development centers, 551 beauty salons, and flower shops among others, which are usually located in the buildings'

552 basement or ground floor. The notable difference of this neighborhood from the one described in

553 the previous case is a yard with various children's playgrounds and football and basketball courts.

554 Currently, apartments in these buildings are privately owned or rented out. The location of the

555 neighborhood on the river's bank as well as in the geographic center of the city makes this 556 residential area attractive to city residents. The case study building has 16 floors and a total of 64 557 apartments. The average energy consumption is around $120 \mathrm{~kW} / \mathrm{h}$ per person, which is higher than 558 the average energy consumption in Nur-Sultan, but lower than that of "Case 1" building. The R559 value for the building materials used for wall construction was calculated to be $17.2 \mathrm{~W} / \mathrm{m}^{2} \mathrm{~K}$. The 560 best performing category is ECO with an exceptionally high score of 8.0 which is the maximum 561 achieved score in this category among all assessed buildings. The overall RSAM score of this 562 residential building is 5.5 which is an impressive result given the average performance score (5.3) 563 of the supposedly more sustainable new-generation buildings evaluated in the present study.

\subsubsection{Case 3: new residential building (lowest sustainability score)}

567 A building built in 2004 was selected from a residential area of Nur-Sultan located in a wealthier 568 part of the city. This area has been constructed in order to provide accommodation for the fast569 growing population of Nur-Sultan after its appointment as the capital city. However, not all the 570 new buildings were good quality construction. This, in the past, has been evident after strong wind 571 events during which façade materials of buildings of poor-quality build got damaged easily. Such 572 residential areas are quite common and at present, they usually provide accommodation for people 
573 working in nearby governmental agencies. The case study building consists of seven floors and a

574 total of 114 apartments. The average monthly energy consumption was $98 \mathrm{kWh}$ per person, which

575 is slightly lower than the city-wide average. Overall, the building's sustainability performance was

576 rated low in many sub-categories. The lowest score category-wise was obtained in ENV category

577 (2.9), it is possible that sustainability in general, as well as environmental aspects, have not been

578 considered in the building's design at that time. Despite the proximity to various amenities, the

579 occupants expressed dissatisfaction with the accessibility of amenities, and social and functional

580 dimensions of the residential area. More specifically, S\&F5 indicator ("facilities") was estimated

581 to be only 4.1. Another significantly lower score of 2.5 was scored in ECO2 ("local economy")

582 indicator indicating the absence of affordable solutions for householders. However, the building

583 scored high results in indicators such as, for example, S\&F4 ("space flexibility and adaptability")

584 and S\&F1 ("user's health and comfort"). These results suggest that such buildings would tend to

585 be more attractive for higher-income occupants. All in all, the overall RSAM score of the building 586 is 4.4, which is lower than the score of "Case 2" building built much earlier.

\subsubsection{Case 4: new residential building (highest sustainability score)}

A representative complex from the newest generation buildings group which received high scores

592 The selected residential complex is built close to an artificial lake and is positioned as a green 593 neighborhood with the integration of renewable energy technologies such as solar panels, wind 594 turbines, and piezoelectric energy harvesting devices mainly used to supply outdoor lighting 595 devices. The apartments are privately owned by individuals or rented out. The location of the 
complex is convenient in terms of transport accessibility, presence of various outdoor amenities, and proximity to business and cultural areas of the city. The case study residential complex contains buildings with $8,10,12$, and 15 floors with a total number of 620 apartments. The average monthly energy consumption is $110 \mathrm{kWh}$ per person and the calculated R-value of the exterior wall for the assessed buildings is $8.7 \mathrm{~W} / \mathrm{m}^{2} \mathrm{~K}$. The complex showed outstanding results in $\mathrm{S} \& \mathrm{~F}$ category by scoring 7.9 points. ECO factor is another area where the building performed well by implemented a wide set of green building measures. For example, it is estimated that the complex saves up to $19 \%$ of energy due to various energy-efficient solutions and passive design. Moreover, the complex collects and reuses greywater achieving reduction up to $32 \%$ in water consumption 606 compared to conventional buildings in Nur-Sultan. However, the residents rated ENV1 ("energy") 607 and ENV4 ("water") poorly resulting in poor performance of the complex in ENV factor (3.7), 608 which is still the best score among all assessed residential buildings. Overall, "Case 4" building 609 complex achieved a higher level of sustainability in two out of three main areas of RSAM assessment, and its sustainability performance was assessed as 6.3.

\subsection{Comparison of RSAM structure with established methods for existing buildings}

613

614 Two well-established sustainability rating systems dedicated to the assessment of existing 615 buildings, LEED-EBOM (USGBC 2014) and Green Star SA EBP (GBCSA 2014), were compared 616 to the resultant structure of the RSAM framework. All three methods recognize the importance of 617 the efficient use of energy and allocate correspondingly great weighting to this category. However, 618 neither LEED-EBOM nor Green Star SA have incorporated heat loss and insulation into their 
assessment framework, while RSAM emphasizes its essence due to the considerable negative impact of coal-powered combined heating and power systems widespread in Kazakhstan on the environment. Moreover, LEED-EBOM and RSAM promote the use of renewable energy sources which is overlooked by Green Star SA. Nonetheless, RSAM considers only green energy produced on-site, whereas LEED-EBOM takes into account the use of off-site renewable energy, too. All three methods encourage the building's owner or management to support and protect the site's ecology as well as favor previously built areas. Moreover, all sustainability assessment tools include solid waste management (i.e. waste separation and storage) and water use efficiency into the sustainability level evaluation process. Though they all require proper collection and management of stormwater (e.g. use it for irrigation purposes), only RSAM considers the recycling and reuse of greywater with its separation from black water.

One key difference between RSAM and the existing two methods is that the former accounts for the economic aspect of sustainability by measuring initial and operational costs of the building and promoting the use of local goods and services which helps to balance the evaluation outcome between the pillars. Another considerable difference between RSAM and the available methods is that the proposed rating system encourages the use of natural ventilation, but LEED-EBOM and Green Star SA do not differentiate between mechanical and natural ventilation systems as long as the desired level of indoor air quality is achieved. The toxicity levels of interior spaces seem to be a major concern for all of the methods, as well as the use of natural light and the thermal and visual comfort of occupants. However, only RSAM encourages the incorporation of passive systems and considering the layout and orientation of the building for minimizing the need for cooling, heating, and mechanical ventilation. 
641 LEED-EBOM, Green Star SA EBP, and RSAM all emphasize the importance of the availability

642 of alternative transport options, but RSAM performs a thorough assessment of sustainability

643 performance of the building by including occupant safety, accessibility, availability of social areas

644 for bringing people together, and space optimization and flexibility in the equation. What RSAM

645 does not include, in comparison to LEED-EBOM and Green Star SA EBP, is the evaluation of

646 parameters such as green cleaning, sustainable purchasing, innovative approach to sustainability,

647 and refrigerants management - concepts which are still new to Kazakhstan, therefore, might

648 compromise the survey speed and quality as they may require detailed explanations for

649 householders and if not understood may lead to poor quality answers. All in all, there are numerous

650 similarities along with some important differences between the established rating systems and the

651 proposed method mainly due to three reasons: (1) the RSAM method aims to cover the pillars of

652 sustainability evenly, (2) a few indicators are left out as they cannot be effectively evaluated via

653 occupant surveys, and (3) the method's content is significantly affected by the regional context, in 654 the present case, of Kazakhstan.

655

6564 Conclusions and Implications

657

658 A fast and resource-efficient sustainability assessment method, Rapid Sustainability Assessment

659 Method (RSAM), has been designed based on stakeholders' perceptions and opinions evenly

660 covering the three pillars of sustainability (environmental, economic, social and functional). Then,

661 it has been used to rate the sustainability performance of selected existing residential buildings

662 representative of different eras in Nur-Sultan (formerly Astana), Kazakhstan. The assessments

663 were based on the responses of the buildings' occupants to questionnaires. It has identified key 
664 differences in the sustainability performances of buildings of three different generations (built 665 during the Soviet era i.e. prior to 1991, built between 1991 and 1998 following Kazakhstan's 666 independence, and built after 1998 when Nur-Sultan city has become the country's capital). Out 667 of three main sustainability categories, the environmental aspect of the residential building sector 668 has the lowest performance rating, which nonetheless has gradually improved over the years. For 669 further improvement, adopting the developed methodology will allow the construction sector and 670 governmental agencies to understand the sustainability condition of individual residential 671 buildings in the city or country for a relatively low cost. The method can also be modified to 672 expand the assessment to non-residential buildings. These, in combination, would further enable 673 the use of assessment results for decision-making at governmental level for the improvement of 674 building sustainability performances for new constructions in the future.

675 There were certain limitations to the present research. First, the sustainability research in 676 Kazakhstan in general and sustainability of buildings in particular is limited to only a few studies 677 (Tokbolat and Calay 2015, Tokbolat et al. 2018, Akhanova et al. 2020). Furthermore, the domain 678 of sustainability is new to the general public requiring some on-site education on the subject prior 679 to the survey. This, along with the subjectivity of responses to certain sub-indicator questions (e.g. 680 perceived average temperature) made the data collection and analysis a labor-intensive process. In 681 the case of older buildings, the data were often less elaborate and required additional processing 682 due to the absence of measuring devices (meters) or unavailability of records, preventing the 683 residents from reporting accurate data such as energy or water consumption.

684 One of the most important features of RSAM framework is its flexibility allowing modifications 685 on the structure (addition or omission of any indicator or sub-indicator) and the weighting system 686 (assigning weights acquired for a specific region or context). This flexibility gives an opportunity 
687 to re-purpose the framework to either include wide range of buildings or focus on a particular type depending on the goals of such sustainability assessment.

689 Given the relatively young age of the capital city and very limited construction before the second 690 half of 20th century, traditional and historic buildings in Nur-Sultan are rare. Moreover, the current 691 state of construction sector in the city favors new construction which is much more profitable than 692 renovating old buildings. However, if the framework is to be applied to an older city (e.g. Almaty, 693 the cultural center of Kazakhstan with over a century-long history), it can be adjusted to account 694 for cultural, social, and other benefits that renovating traditional and historical buildings brings. 695 The existing structure of the framework already favors reusing old buildings with an inclusion of 696 sub-indicators like "reuse of previously built or contaminated areas", but it may omit other 697 significant factors. Some of the suggested major aspects of adaptive reuse of old historic buildings 698 include "heritage preservation" and "appropriateness of the new scope" of the building, which can 699 be easily added as indicators or sub-indicators to social and functional factor $(\mathrm{S} \& \mathrm{~F})$. Other aspects 700 such as "the contribution of the building to revitalization of the area" and "increased tourism" may 701 also be important (Misirlisoy and Gunce 2016), but they might pose a challenge in finding rapid 702 and easy ways to rate these aspects. On the contrary, some sub-indicators including the initial costs 703 of construction might have to be changed or overlooked in order to assess renovation costs. These 704 kinds of adjustments would require iterating the process of framework development starting from 705 choosing appropriate indicators and sub-indicators as well as ways to measure them and ending 706 with developing a new weighting system derived from stakeholders' opinions adding a great 707 prospect in RSAM improvement in the future.

708 RSAM has the potential to become a good alternative to elaborate and resource-intensive 709 international sustainability certification tools. The recommended future work includes (1) the 
710 development of a user-friendly online tool with an easy-to-navigate structure (to make the adoption

711 of RSAM easier for stakeholders), (2) building a city-wide sustainability map with the help of

712 stakeholders and governmental agencies to access larger quantities of building information (to aid

713 the decision-making process of the municipality in improving urban sustainability), and (3) to

714 develop a causality model for RSAM parameters which can measure householders' loyalty and

715 satisfaction levels for housing developers (to understand the correlation between various

716 sustainability-related variables and the clients' satisfaction, to view subsequent changes in

717 satisfaction levels after making adjustments to building-related variables during design and

718 construction phases).

719

720 Acknowledgments

721

722 The authors acknowledge the financial support provided by Nazarbayev University.

723

$724 \quad$ References

725 Aigbavboa, C., Ohiomah, I., and Zwane, T. (2017). Sustainable construction practices: "a lazy view" of 726 construction professionals in the South Africa construction industry. Energy Procedia, 105, 3003-3010. 727 https://doi.org/10.1016/j.egypro.2017.03.743.

728 Akhanova, G., Nadeem, A., Kim, J., et al. (2020). A multi-criteria decision-making framework for building 729 sustainability assessment in Kazakhstan. Sustainable Cities and Societies, 52. 730 https://doi.org/10.1016/j.scs.2019.101842.

731 Alhumaidi, H. M. (2016). An evaluation of existing environmental buildings' rating systems and suggested 732 sustainable material selection assessment criteria. WIT Transactions on Ecology and The Environment, $733210,111-122$. https://doi.org/10.2495/SDP160101. 
Ali, H. H., and Al Nsairat, S. F. (2009). Developing a green building assessment tool for developing countries - case of Jordan. Building and Environment, 44, 1053-1064. https://doi.org/10.1016/j.buildenv.2008.07.015.

Al-Jebouri, M. F. A., Saleh, M. S., Raman, S. N., et al. (2017). Toward a national sustainable building assessment system in Oman: Assessment categories and their performance indicators. Sustainable Cities and Society, 31, 122-135. https://doi.org/10.1016/j.scs.2017.02.014.

AlWaer, H., Sibley, M., and Lewis, J. (2008). Different stakeholder perceptions of sustainability assessment. Architectural Science Review, 51, 48-59. https://doi.org/10.3763/asre.2008.5107.

Asdrubali, F., Baldinelli, G., Bianchi, F., et al. (2015). A comparison between environmental sustainability rating systems LEED and ITACA for residential buildings. Building and Environment, 86, 98-108. https://doi.org/10.1016/j.buildenv.2015.01.001.

Bal, M., Bryde, D., Fearon, D., et al. (2013). Stakeholder engagement: achieving sustainability in the construction sector. Sustainability 6, 695-710. https://doi.org/10.3390/su5020695.

Banani, R., Vahdati, M., and Elmualim, A. (2013). Demonstrating the importance of criteria and sub-criteria in building assessment methods. WIT Transactions on Ecology and The Environment, 173, 443-454. https://doi.org/10.2495/sdp130371.

Banani, R., Vahdati, M., Shahrestani, M., et al. (2016). The development of building assessment criteria framework for sustainable non-residential buildings in Saudi Arabia. Sustainable Cities and Society, 26, 289-305. http://dx.doi.org/10.1016/j.scs.2016.07.007.

Boecker, J., Horst, S., Keiter, A. L., et al. (2009). The integrative design guide to building green - redefining the practice of sustainability. Wiley, Hoboken, NJ, USA.

Bryson, J. M. (2004). What to do when stakeholders matter: stakeholder identification and analysis techniques. Public Management Review, 6, 21-53.

Building Research Establishment Ltd (BRE). 2011. BREEAM New Construction: Non-Domestic Buildings.

Kridlova Burdova, E., and Vilcekova, S. (2015). Sustainable Building Assessment Tool in Slovakia. 6th International Building Physics Conference, IBPC 2015. Energy Procedia, 78, 1829-1834.

Castro-Lacouture, D., Sefair, J. A., Flórez, L., et al. (2009). Optimization model for the selection of materials using a LEED-based green building rating system in Colombia. Building and Environment, 44, 1162-170. https://doi.org/10.1016/j.buildenv.2008.08.009. 
Cole, R. J. (1999). Building environmental assessment methods: Clarifying intentions. Building Research and Information, 27, 230-246. https://doi.org/10.1080/096132199369354.

Cronbach, L. J. (1951). Coefficient alpha and the internal structure of tests. Psychometrika, 16, 297-334. https://doi.org/10.1007/bf02310555.

Darus, Z. M., Hashim, N. A., Salleh, E., et al. (2009, March). Development of rating system for sustainable building in Malaysia. WSEAS Transactions on Environment and Development 5: 260-272. https://pdfs.semanticscholar.org/d1f7/26b6b70aba06a76483497f4ece95eefd2b9e.pdf.

Ding, G. K. C. (2008). Sustainable construction - The role of environmental assessment tools. Journal of Environmental Management, 86, 451-464. https://doi.org/10.1016/j.jenvman.2006.12.025.

Energy Sector Management Assistance Program (ESMAP). (2017). Municipal Energy Efficiency Plan for the City of Astana. http://documents.worldbank.org/curated/en/ 362411510931587832/pdf/121462ESM-P130013-PUBLIC-KEEPAstanaEEPlanNovengfinal.pdf.

Energy Sector Management Assistance Program (ESMAP). (2018). Synthesis Report: Unlocking Energy Efficiency Potentials in Cities in Kazakhstan. http://documents.worldbank.org/curated/en/267161521612788850/pdf/124484-ESM-PUBLICP130013-SynthesisMarchFinal.pdf.

Freeman, R. E. (1984). Strategic Management: A Stakeholder Approach. (1st ed.). Boston: Pitman Publishing.

Freeman, R. E., Harrison, J. S., and Wicks, A. C. (2007). Managing stakeholders: Survival, reputation and success. New Haven: Yale University Press.

Freeman, R. E., Harrison, J. S., and Wicks, A. C., et al. (2010). Stakeholder theory: The state of the art. Cambridge: Cambridge University Press.

Forsberg, A., and von Malmborg, F. (2004). Tools for environmental assessment of the built environment. Building and Environment, 39, 223-228. https://doi.org/10.1016/j.buildenv.2003.09.004.

Gan, X. L., Zuo, J., Ye, K. H., et al. (2015). Why sustainable construction? Why not? An owner's perspective. Habitat International, 47, 61-68. https://doi.org/10.1016/j.habitatint.2015.01.005.

George, D., and Mallery, P. (2003). SPSS for Windows step by step: A simple guide and reference, 11.0 update. (4th ed.). Boston: Allyn \& Bacon.

Gou, Z., and Xie, X. (2017). Evolving green building: triple bottom line or regenerative design? Journal of Cleaner Production, 153, 600-07. https://doi.org/10.1016/j.jclepro.2016.02.077. 
Green Building Council of Australia (GBCA). (2009). Technical Manual Green Star Multi Unit Residential.

Green Building Council of South Africa (GBCSA). (2014). Green Star SA - Existing Building Performance Pilot.

Haapio, A., and Viitaniemi, P. (2008). A critical review of building environmental assessment tools. Environmental Impact Assessment Review, 28, 469-82. https://doi.org/10.1016/j.eiar.2008.01.002.

Hair, J. F., Black, W. C., Babin, B. J., et al. (2010). Multivariate data analysis. (7th ed.). Harlow: Pearson Education Ltd.

Heravi, A., Coffey, V., and Trigunarsyah, B. (2015). Evaluating the level of stakeholder involvement during the project planning processes of building projects. International Journal of Project Management, 33, 985-997. https://10.1016/j.ijproman.2014.12.007.

Herazo, B., and Lizarralde, G. (2016). Understanding stakeholders' approaches to sustainability in building projects. Sustainable Cities and Society, 26, 240-254. http://dx.doi.org/10.1016/j.scs.2016.05.019.

International Institute for Applied Systems Analysis (IIASA). (2012). Global energy assessment: Toward a sustainable future. Cambridge: Cambridge University Press.

Intergovernmental Panel on Climate Change (IPCC). (2014). Climate change 2014: Synthesis report. Geneva: IPCC.

ITE Build \& Interiors. (2016). The future of building looks green in Kazakhstan. http://www.buildingshows.com/market-insights/Kazakhstan/The-future-of-building-looks-green-inKazakhstan/801816831. Accessed 11 November 2019.

Japan Sustainable Building Consortium (JSBC). (2005). CASBEE for new construction - technical manual 2004 Edition. Tokyo: Institute for Building Environment and Energy Conservation.

Lee, D. (2016). Filtered, bottled or tap: what kind of water to drink in Astana. https://astanatimes.com/2016/04/filtered-bottled-or-tap-what-kind-of-water-to-drink-in-astana/ Accessed 11 November 2019.

Mahmoud, S., Zayed, T., and Fahmy, M. (2019). Development of sustainability assessment tool for existing buildings. Sustainable Cities and Society, 44, 99-119. https://doi.org/10.1016/j.scs.2018.09.024.

Makuei, A. M. J., and Oladapo, A. (2014). Stakeholders' perception of sustainable construction in South Sudan. Conference paper. Proceedings of the CIB W107 2017 International Conference, Lagos, Nigeria, $28^{\text {th }}-30^{\text {th }}$ January, 2014. 
Mascarenhas, A., Nunes, L. M., and Ramos, T. B. (2014). Exploring the self-assessment of sustainability indicators by different stakeholders. Ecological Indicators, 39, 75-83. https://doi.org/10.1016/j.ecolind.2013.12.001.

Mateus, R., and Bragança, L. (2011). Sustainability assessment and rating of buildings: developing the methodology SBToolPT-H. Building and Environment, 46, 1962-1971. https://doi.org/10.1016/j.buildenv.2011.04.023.

Mathur, V. N., Price, A. D. F., and Austin, S. (2008). Conceptualizing stakeholder engagement in the context of sustainability and its assessment. Construction Management and Economics, 26, 601-609. https://doi.org/10.1080/01446190802061233.

Misirlisoy, D., and Gunce, K. (2016). A critical look to the adaptive reuse of traditional urban houses in the Walled City of Nicosia. Journal of Architectural Conservation, 22, 149-166. https://doi.org/10.1080/13556207.2016.1248095.

Nunnally, J. C. (1967). Psychometric theory. New York: McGraw-Hill.

Ojoko, E. O., Osman, M. H., Rahman, A. B. A., et al. (2018). Evaluating the critical success factors of industrialized building system implementation in Nigeria: the stakeholders' perception. International Journal of Built Environment and Sustainability, 5, 127-133. https://doi.org/10.11113/ijbes.v5.n2.240.

Reijnders, L. and van Roekel, A. (1999). Comprehensiveness and adequacy of tools for the environmental improvement of buildings. Journal of Cleaner Production, 7, 221-225. https://doi.org/10.1016/S09596526(99)00080-3.

Reimann, C., Filzmoser, P., Garret, R., et al. (2008). Statistical data analysis explained. (1st ed.). Chichester: John Wiley \& Sons Ltd.

Seppo, J. (2004). The environmental impact of an office building throughout its life cycle. Dissertation, Helsinki University of Technology; Espoo, Finland.

Stephan, K., and Menassa, C. C. (2015). Modeling the effect of building stakeholder interactions on value perception of sustainable retrofits. Journal of Computing in Civil Engineering, 29. https://doi.org/10.1061/(asce)cp.1943-5487.0000409.

Taisch, M., Sadr, V., May, G., et al. (2013). Sustainability Assessment Tools - State of Research and Gap Analysis. IFIP Advances in Information and Communication Technology Advances in Production Management Systems. Sustainable Production and Service Supply Chains, 415, 426-434. https://doi.org/10.1007/978-3-642-41263-9_53. 
Tokbolat, S., and Calay, R. (2015). Residential construction sustainability in the UK and prospects of knowledge transfer to Kazakhstan. Journal of Sustainable Development, 8, 14-23. https://doi.org/10.5539/jsd.v8n9p14.

Tokbolat, S., Karaca, F., Durdyev, S., et al. (2018). Assessment of green practices in residential buildings: a survey based empirical study of residents in Kazakhstan. Sustainability, 10, 4383-4399. https://doi.org/10.3390/su10124383.

Todd, J. A., and Geissler, S. (1999). Regional and cultural issues in environmental performance assessment for buildings. Building Research and Information, 27, 247-256. https://doi.org/10.1080/096132199369363.

Toor, S. R., and Ogunlana, S. O. (2009). Construction professionals' perception of critical success factors for large-scale construction projects. Construction Innovation, 9, 149-167. https://doi.org/10.1108/14714170910950803.

United Nations Environment Programme (UNEP). (2015). Global Waste Management Outlook.

UNDP Kazakhstan and Global Environmental Facility. (2013). Removing Barriers to Energy Efficiency in Municipal Heat Hot Water Supply. http://www.eurasia.undp.org/content/dam/rbec/docs/Removing\%20barriers\%20to\%20energy.pdf. Accessed 11 November 2019.

U.S. Green Building Council (USGBC). (2009). LEED v4 for building design and construction.

U.S. Green Building Council (USGBC). (2014). LEED 2009 for Existing Buildings Operations and Maintenance Rating System. Washington: U.S. Green Building Council.

Yudelson, J. (2008). Marketing Green Building Services. London: Routledge.

Zhang, Y., Wang, J., Hu, F., et al. (2017). Comparison of evaluation standards for green building in China, Britain, United States. Renewable and Sustainable Energy Reviews, 68, 262-71. https://doi.org/10.1016/j.rser.2016.09.139. 
879 Table 1. Comparison of sub-indicators of Rapid Sustainability Assessment Method (RSAM) with

880 LEED - Existing Buildings: Operations \& Maintenance (EBOM) and Green Star for Existing 881 Building Performance (SA EB)

\begin{tabular}{|c|c|c|}
\hline Sub-indicators of RSAM & $\begin{array}{l}\text { LEED - } \\
\text { EBOM }\end{array}$ & $\begin{array}{c}\text { Green Star } \\
\text { SA EB }\end{array}$ \\
\hline ENV1.1: Primary energy consumption/area (or volume) (Energy efficiency rating) & $\mathrm{X}$ & $\mathrm{X}$ \\
\hline \multicolumn{3}{|l|}{ ENV1.2: Heat loss/Insulation } \\
\hline ENV1.3: Local energy production & $\mathrm{X}$ & \\
\hline \multicolumn{3}{|l|}{ ENV2.1: Layout optimization } \\
\hline \multicolumn{3}{|l|}{ ENV2.2: Soil sealing } \\
\hline ENV2.3: Reuse of previously built or contaminated areas & $\mathrm{X}$ & $\mathrm{X}$ \\
\hline ENV2.4: Ecological protection of the site & $\mathrm{X}$ & $\mathrm{X}$ \\
\hline ENV2.5: Rehabilitation of the surrounding & $\mathrm{X}$ & \\
\hline \multicolumn{3}{|l|}{ ENV2.6: Use of native plants } \\
\hline ENV3.2: Reused products and recycled materials & $\mathrm{X}$ & $\mathrm{X}$ \\
\hline ENV3.3: Waste separation and storage & $\mathrm{X}$ & $\mathrm{X}$ \\
\hline ENV4.1: Water consumption & $\mathrm{X}$ & $\mathrm{X}$ \\
\hline \multicolumn{3}{|l|}{ ENV4.2: Recycling and reuse of grey water } \\
\hline ENV4.3: Rain and storm water collection and use & $\mathrm{X}$ & $\mathrm{X}$ \\
\hline \multicolumn{3}{|l|}{ ENV4.4: Separation of black water } \\
\hline \multicolumn{3}{|l|}{ ECO1.1: Initial costs (cost of the building) } \\
\hline \multicolumn{3}{|l|}{ ECO1.2: Operational costs (e.g. energy and water consumption costs) } \\
\hline \multicolumn{3}{|l|}{ ECO2.1: Hiring local goods and services } \\
\hline \multicolumn{3}{|l|}{ S\&F1.1: Natural ventilation } \\
\hline S\&F1.2: Toxicity of finishing materials & $\mathrm{X}$ & $\mathrm{X}$ \\
\hline S\&F1.3: Thermal comfort & $\mathrm{X}$ & $\mathrm{X}$ \\
\hline S\&F1.4: Visual comfort & $\mathrm{X}$ & $\mathrm{X}$ \\
\hline S\&F1.5: Acoustic comfort & & $\mathrm{X}$ \\
\hline S\&F1.6: Indoor air quality & $\mathrm{X}$ & $\mathrm{X}$ \\
\hline S\&F1.7: Natural light & $\mathrm{X}$ & $\mathrm{X}$ \\
\hline \multicolumn{3}{|l|}{ S\&F2.1: Layout and orientation } \\
\hline \multicolumn{3}{|l|}{ S\&F2.2: Passive systems (e.g. no electric ventilation, cooling and heating, etc.) } \\
\hline \multicolumn{3}{|l|}{ S\&F3.1: Occupant safety } \\
\hline \multicolumn{3}{|l|}{ S\&F3.2: Accessibilities } \\
\hline \multicolumn{3}{|l|}{ S\&F4.1: Availability and accessibility to social areas } \\
\hline \multicolumn{3}{|l|}{ S\&F4.2: Space optimization, flexibility and adaptability } \\
\hline S\&F5.1: Accessibility to public transport & $\mathrm{X}$ & $\mathrm{X}$ \\
\hline \multicolumn{3}{|l|}{ S\&F5.2: Local amenities } \\
\hline S\&F5.3: Low impact mobility & $\mathrm{X}$ & $\mathrm{X}$ \\
\hline S\&F5.4: Building management and availability of services & & $X$ \\
\hline
\end{tabular}


882 Table 2. Data on participants belonging to one of the three stakeholder groups $(n=68)$

\begin{tabular}{|c|c|c|}
\hline & Stakeholder groups & Description of participants \\
\hline \multirow[t]{2}{*}{ Public } & $\begin{array}{l}\text { PG: People with graduate degree } \\
\qquad(\mathrm{n}=15)\end{array}$ & $\begin{array}{l}\text { Specialists, managers, graduate students, } \\
\text { engineers (civil, environmental, mechanical, } \\
\text { electrical), research assistants, teaching } \\
\text { assistants }\end{array}$ \\
\hline & $\begin{array}{l}\text { PU: People with undergraduate } \\
\text { degree and/or with high school } \\
\text { degree }(n=20)\end{array}$ & $\begin{array}{l}\text { Accountants, auditors, students, high school } \\
\text { graduates, businessmen, teachers, doctors }\end{array}$ \\
\hline Academy & $\begin{array}{l}\text { AC: University professors } \\
\qquad(\mathrm{n}=15)\end{array}$ & Professors at various levels \\
\hline \multirow{2}{*}{$\begin{array}{l}\text { Construction } \\
\text { industry }\end{array}$} & CO: Office workers $(\mathrm{n}=9)$ & $\begin{array}{l}\text { Architects, computing engineers, project } \\
\text { managers, structural engineers, pumping } \\
\text { engineers, electrical engineers }\end{array}$ \\
\hline & CF: Field workers $(n=9)$ & $\begin{array}{l}\text { Foremen, chief managers, project managers, } \\
\text { technical document specialists, project group } \\
\text { specialists, chief engineers, site engineers }\end{array}$ \\
\hline
\end{tabular}


Table 3. Hierarchical structure of RSAM framework with weight summaries

\begin{tabular}{|c|c|c|c|c|c|}
\hline $\begin{array}{l}\text { Level } 1 \\
\text { (Factors) }\end{array}$ & $\begin{array}{c}\text { Weights } \\
{[1-5]}\end{array}$ & $\begin{array}{l}\text { Level } 2 \\
\text { (Indicators) }\end{array}$ & $\begin{array}{c}\text { Weights } \\
{[1-5]}\end{array}$ & $\begin{array}{l}\text { Level } 3 \\
\text { (Sub-indicators) }\end{array}$ & $\begin{array}{c}\text { Weights } \\
{[1-5]}\end{array}$ \\
\hline \multirow[t]{15}{*}{$\begin{array}{l}\text { ENV: } \\
\text { Environmental }\end{array}$} & \multirow[t]{15}{*}{4.57} & \multirow[t]{3}{*}{$\begin{array}{l}\text { ENV1: } \\
\text { Energy }\end{array}$} & \multirow[t]{3}{*}{4.65} & $\begin{array}{l}\text { ENV1.1: Primary energy } \\
\text { consumption/area (or } \\
\text { volume) (Energy Efficiency } \\
\text { rating) }\end{array}$ & 4.47 \\
\hline & & & & ENV1.2: Heat loss/insulation & 4.56 \\
\hline & & & & $\begin{array}{l}\text { ENV1.3: Local energy } \\
\text { production }\end{array}$ & 4.08 \\
\hline & & \multirow{6}{*}{$\begin{array}{l}\text { ENV2: Soil } \\
\text { use and } \\
\text { biodiversity }\end{array}$} & \multirow[t]{6}{*}{3.99} & ENV2.1: Layout optimization & 4.03 \\
\hline & & & & ENV2.2: Soil sealing & 4.05 \\
\hline & & & & $\begin{array}{l}\text { ENV2.3: Reuse of previously } \\
\text { built or contaminated areas }\end{array}$ & 3.51 \\
\hline & & & & $\begin{array}{l}\text { ENV2.4: Ecological } \\
\text { protection of the site }\end{array}$ & 4.20 \\
\hline & & & & $\begin{array}{l}\text { ENV2.5: Rehabilitation of } \\
\text { the surrounding }\end{array}$ & 3.95 \\
\hline & & & & ENV2.6: Use of native plants & 3.71 \\
\hline & & \multirow{2}{*}{$\begin{array}{l}\text { ENV3: } \\
\text { Materials } \\
\text { and Solid } \\
\text { Waste }\end{array}$} & \multirow[t]{2}{*}{4.15} & $\begin{array}{l}\text { ENV3.1: Reused products } \\
\text { and recycled materials }\end{array}$ & 4.07 \\
\hline & & & & $\begin{array}{l}\text { ENV3.2: Waste separation } \\
\text { and storage }\end{array}$ & 4.31 \\
\hline & & \multirow{4}{*}{$\begin{array}{l}\text { ENV4: } \\
\text { Water }\end{array}$} & \multirow[t]{4}{*}{4.58} & ENV4.1: Water consumption & 4.53 \\
\hline & & & & $\begin{array}{l}\text { ENV4.2: Recycling and reuse } \\
\text { of grey water }\end{array}$ & 3.87 \\
\hline & & & & $\begin{array}{l}\text { ENV4.3: Rain and storm } \\
\text { water collection and use }\end{array}$ & 3.53 \\
\hline & & & & $\begin{array}{l}\text { ENV4.4: Separation of black } \\
\text { water }\end{array}$ & 3.79 \\
\hline \multirow[t]{4}{*}{$\begin{array}{l}\text { ECO: } \\
\text { Economic }\end{array}$} & \multirow[t]{3}{*}{4.41} & \multirow[t]{2}{*}{$\begin{array}{l}\text { ECO1: Cost } \\
\text { of building }\end{array}$} & \multirow[t]{2}{*}{4.47} & $\begin{array}{l}\text { ECO1.1: Initial costs (cost of } \\
\text { the building) }\end{array}$ & 4.33 \\
\hline & & & & $\begin{array}{l}\text { ECO1.2: Operational costs } \\
\text { (e.g. energy and water } \\
\text { consumption costs) }\end{array}$ & 4.63 \\
\hline & & $\begin{array}{l}\text { ECO2: } \\
\text { Local } \\
\text { Economy }\end{array}$ & 4.13 & $\begin{array}{l}\text { ECO2.1: Hiring local goods } \\
\text { and services }\end{array}$ & 4.13 \\
\hline & 4.51 & & 4.53 & S\&F 1.1: Natural ventilation & 4.61 \\
\hline
\end{tabular}




\begin{tabular}{|c|c|c|c|c|c|}
\hline $\begin{array}{l}\text { Level } 1 \\
\text { (Factors) }\end{array}$ & $\begin{array}{c}\text { Weights } \\
{[1-5]}\end{array}$ & $\begin{array}{l}\text { Level } 2 \\
\text { (Indicators) }\end{array}$ & $\begin{array}{c}\text { Weights } \\
\text { [1-5] }\end{array}$ & $\begin{array}{l}\text { Level } 3 \\
\text { (Sub-indicators) }\end{array}$ & $\begin{array}{c}\text { Weights } \\
{[1-5]}\end{array}$ \\
\hline \multirow{16}{*}{$\begin{array}{l}\text { S\&F: Social } \\
\text { and functional }\end{array}$} & & \multirow{6}{*}{$\begin{array}{l}\text { S\&F1: } \\
\text { User's } \\
\text { health and } \\
\text { comfort }\end{array}$} & & $\begin{array}{l}\text { S\&F 1.2: Toxicity of } \\
\text { finishing materials }\end{array}$ & 4.61 \\
\hline & & & & S\&F1.3: Thermal comfort & 4.61 \\
\hline & & & & S\&F1.4: Visual comfort & 4.31 \\
\hline & & & & S\&F1.5: Acoustic comfort & 4.53 \\
\hline & & & & S\&F1.6: Indoor air quality & 4.69 \\
\hline & & & & S\&F1.7: Natural light & 4.43 \\
\hline & & \multirow{2}{*}{$\begin{array}{l}\text { S\&F2: } \\
\text { Passive } \\
\text { design }\end{array}$} & \multirow[t]{2}{*}{3.86} & $\begin{array}{l}\text { S\&F2.1: Layout and } \\
\text { orientation }\end{array}$ & 3.92 \\
\hline & & & & $\begin{array}{l}\text { S\&F2.2: Passive systems } \\
\text { (e.g. no electric ventilation, } \\
\text { cooling and heating, etc.) }\end{array}$ & 3.73 \\
\hline & & \multirow{2}{*}{$\begin{array}{l}\text { S\&F3: } \\
\text { Mobility } \\
\text { plan }\end{array}$} & \multirow[t]{2}{*}{3.86} & S\&F3.1: Occupant safety & 4.64 \\
\hline & & & & S\&F3.2: Accessibilities & 4.28 \\
\hline & & \multirow{2}{*}{$\begin{array}{l}\text { S\&F4: } \\
\text { Space } \\
\text { flexibility } \\
\text { and } \\
\text { adaptability }\end{array}$} & \multirow[t]{2}{*}{3.88} & $\begin{array}{l}\text { S\&F4.1: Availability and } \\
\text { accessibility to social areas }\end{array}$ & 4.16 \\
\hline & & & & $\begin{array}{l}\text { S\&F4.2: Space optimization, } \\
\text { flexibility and adaptability }\end{array}$ & 4.09 \\
\hline & & \multirow[t]{4}{*}{$\begin{array}{l}\text { S\&F5: } \\
\text { Facilities }\end{array}$} & \multirow[t]{4}{*}{4.09} & $\begin{array}{l}\text { S\&F5.1: Accessibility to } \\
\text { public transport }\end{array}$ & 4.23 \\
\hline & & & & S\&F5.2: Local amenities & 3.93 \\
\hline & & & & $\begin{array}{l}\text { S\&F5.3: Low impact } \\
\text { mobility }\end{array}$ & 3.71 \\
\hline & & & & $\begin{array}{l}\text { S\&F5.4: Building } \\
\text { management and availability } \\
\text { of services }\end{array}$ & 4.12 \\
\hline
\end{tabular}


888 Table 4. Shapiro-Wilk normality test performed on the collected data from the participants

\begin{tabular}{|c|c|c|c|}
\hline \multirow{2}{*}{ Stakeholder group } & \multicolumn{3}{|c|}{ Shapiro-Wilk test parameters } \\
\cline { 2 - 4 } & Statistic & df & Sig. \\
\hline AC & 0.934 & 51 & 0.006 \\
\hline CF & 0.934 & 51 & 0.007 \\
\hline CO & 0.915 & 51 & 0.001 \\
\hline PG & 0.943 & 51 & 0.015 \\
\hline PU & 0.945 & 51 & 0.019 \\
\hline
\end{tabular}

889

890 
891 Table 5. Kruskal-Wallis test on overall score of stakeholder groups' opinion on all indicators

\begin{tabular}{|c|c|c|c|c|c|}
\hline Levels & df & H value & $\begin{array}{c}\text { Critical } \\
\text { value }\end{array}$ & $\begin{array}{c}P \\
\text { value }\end{array}$ & Conclusion \\
\hline $\begin{array}{l}\text { Level } 3 \text { - } \\
\text { Sub- } \\
\text { indicators }\end{array}$ & 4 & 3644237.8 & 0.7 & $<0.000$ & \multirow{3}{*}{$\begin{array}{l}\text { Not all group medians are equal. } \\
\text { Differences between some of the } \\
\text { medians are statistically significant. } \\
\text { Rejection of null hypothesis. }\end{array}$} \\
\hline $\begin{array}{c}\text { Level } 2 \text { - } \\
\text { Indicators }\end{array}$ & 4 & 138402.8 & 0.7 & $<0.000$ & \\
\hline $\begin{array}{l}\text { Level } 1 \text { - } \\
\text { Factors }\end{array}$ & 4 & 106709.7 & 0.7 & $<0.000$ & \\
\hline
\end{tabular}

892

893 
Table 6. Indicator priorities by all stakeholder groups

\begin{tabular}{|c|c|c|c|c|c|c|c|}
\hline \multirow{2}{*}{$\begin{array}{l}\text { Parameters } \\
\text { Indicators }\end{array}$} & \multicolumn{7}{|c|}{ Number of responses and priority ranking } \\
\hline & 1 & 2 & 3 & 4 & 5 & MS & Rank \\
\hline \multicolumn{8}{|c|}{ A. LEVEL 3 PARAMETERS } \\
\hline Indoor air quality & 0 & 2 & 6 & 17 & 49 & 335 & 1 \\
\hline Natural ventilation & 0 & 1 & 6 & 25 & 40 & 320 & 2 \\
\hline Heat loss/Insulation & 0 & 2 & 2 & 26 & 40 & 314 & 3 \\
\hline Thermal comfort & 0 & 0 & 2 & 33 & 35 & 313 & 4 \\
\hline Acoustic comfort & 0 & 2 & 5 & 22 & 41 & 312 & 5 \\
\hline Toxicity of finishing materials & 0 & 1 & 3 & 20 & 44 & 311 & 6 \\
\hline Water consumption & 0 & 2 & 8 & 13 & 46 & 310 & 7 \\
\hline Natural light & 0 & 4 & 8 & 23 & 37 & 309 & 8 \\
\hline Occupant safety & 0 & 2 & 3 & 19 & 44 & 309 & 8 \\
\hline Primary energy consumption & 0 & 2 & 5 & 23 & 38 & 301 & 9 \\
\hline Operational costs & 0 & 0 & 2 & 20 & 43 & 301 & 9 \\
\hline Visual comfort & 0 & 3 & 10 & 27 & 31 & 299 & 10 \\
\hline Accessibilities & 0 & 5 & 6 & 34 & 27 & 299 & 10 \\
\hline Waste separation and storage & 0 & 2 & 7 & 27 & 32 & 293 & 11 \\
\hline Availability and accessibility to social areas & 0 & 5 & 8 & 38 & 21 & 291 & 12 \\
\hline Accessibility to public transport & 0 & 4 & 9 & 30 & 26 & 285 & 13 \\
\hline Initial costs (cost of the building) & 1 & 3 & 5 & 22 & 35 & 284 & 14 \\
\hline Ecological protection of the site & 0 & 3 & 10 & 24 & 30 & 282 & 15 \\
\hline Space optimization, flexibility and adaptability & 0 & 4 & 14 & 30 & 22 & 280 & 16 \\
\hline Reused products and recycled materials & 0 & 5 & 8 & 32 & 23 & 277 & 17 \\
\hline Building management and availability of services & 0 & 2 & 11 & 32 & 21 & 270 & 18 \\
\hline Local Energy production & 1 & 4 & 11 & 23 & 27 & 268 & 19 \\
\hline Construction waste & 1 & 6 & 11 & 27 & 22 & 263 & 20 \\
\hline Use of native plants & 3 & 9 & 19 & 30 & 13 & 260 & 21 \\
\hline Recycling and reuse of grey water & 2 & 4 & 13 & 29 & 19 & 258 & 22 \\
\hline Local amenities & 0 & 4 & 12 & 33 & 16 & 256 & 23 \\
\hline Soil sealing & 0 & 2 & 16 & 19 & 24 & 248 & 24 \\
\hline Separation of black water & 3 & 6 & 16 & 27 & 16 & 248 & 25 \\
\hline Layout and Orientation & 0 & 3 & 11 & 37 & 12 & 247 & 26 \\
\hline Rehabilitation of the surrounding & 2 & 5 & 11 & 28 & 17 & 240 & 27 \\
\hline Reuse of previously built or contaminated areas & 6 & 7 & 21 & 22 & 14 & 235 & 28 \\
\hline Passive Systems & 3 & 5 & 15 & 24 & 15 & 226 & 29 \\
\hline Rain and storm water collection and use & 3 & 6 & 20 & 26 & 9 & 221 & 30 \\
\hline Heat island effect & 3 & 7 & 15 & 19 & 14 & 205 & 31 \\
\hline
\end{tabular}




\begin{tabular}{|c|c|c|c|c|c|c|c|}
\hline Low impact mobility & 1 & 5 & 19 & 16 & 9 & 176 & 32 \\
\hline \multicolumn{8}{|c|}{ B. LEVEL 2 PARAMETERS } \\
\hline User's health and comfort & 0 & 2 & 6 & 20 & 43 & 317 & 1 \\
\hline Water & 0 & 1 & 6 & 22 & 41 & 313 & 2 \\
\hline Cost of Building & 0 & 2 & 4 & 28 & 36 & 308 & 3 \\
\hline Energy & 0 & 1 & 5 & 15 & 46 & 307 & 4 \\
\hline Materials and Solid Waste & 2 & 1 & 15 & 27 & 26 & 285 & 5 \\
\hline Local Economy & 0 & 2 & 12 & 29 & 25 & 281 & 6 \\
\hline Facilities & 0 & 2 & 6 & 41 & 16 & 266 & 7 \\
\hline Space flexibility and adaptability & 0 & 3 & 17 & 38 & 11 & 264 & 8 \\
\hline Passive design & 0 & 4 & 14 & 32 & 13 & 243 & 9 \\
\hline Mobility plan & 0 & 4 & 19 & 30 & 10 & 235 & 10 \\
\hline Soil use and biodiversity & 0 & 1 & 14 & 32 & 12 & 232 & 11 \\
\hline \multicolumn{8}{|c|}{ C. LEVEL 1 PARAMETERS } \\
\hline Environmental & 0 & 4 & 7 & 18 & 45 & 326 & 1 \\
\hline Economic & 0 & 1 & 4 & 31 & 36 & 318 & 2 \\
\hline Social and functional & 0 & 1 & 6 & 28 & 34 & 302 & 3 \\
\hline
\end{tabular}


897 Figure 1. Comparative (sensitivity) analysis for LEED, BREEAM, Green Star, and CASBEE in terms of major key categories

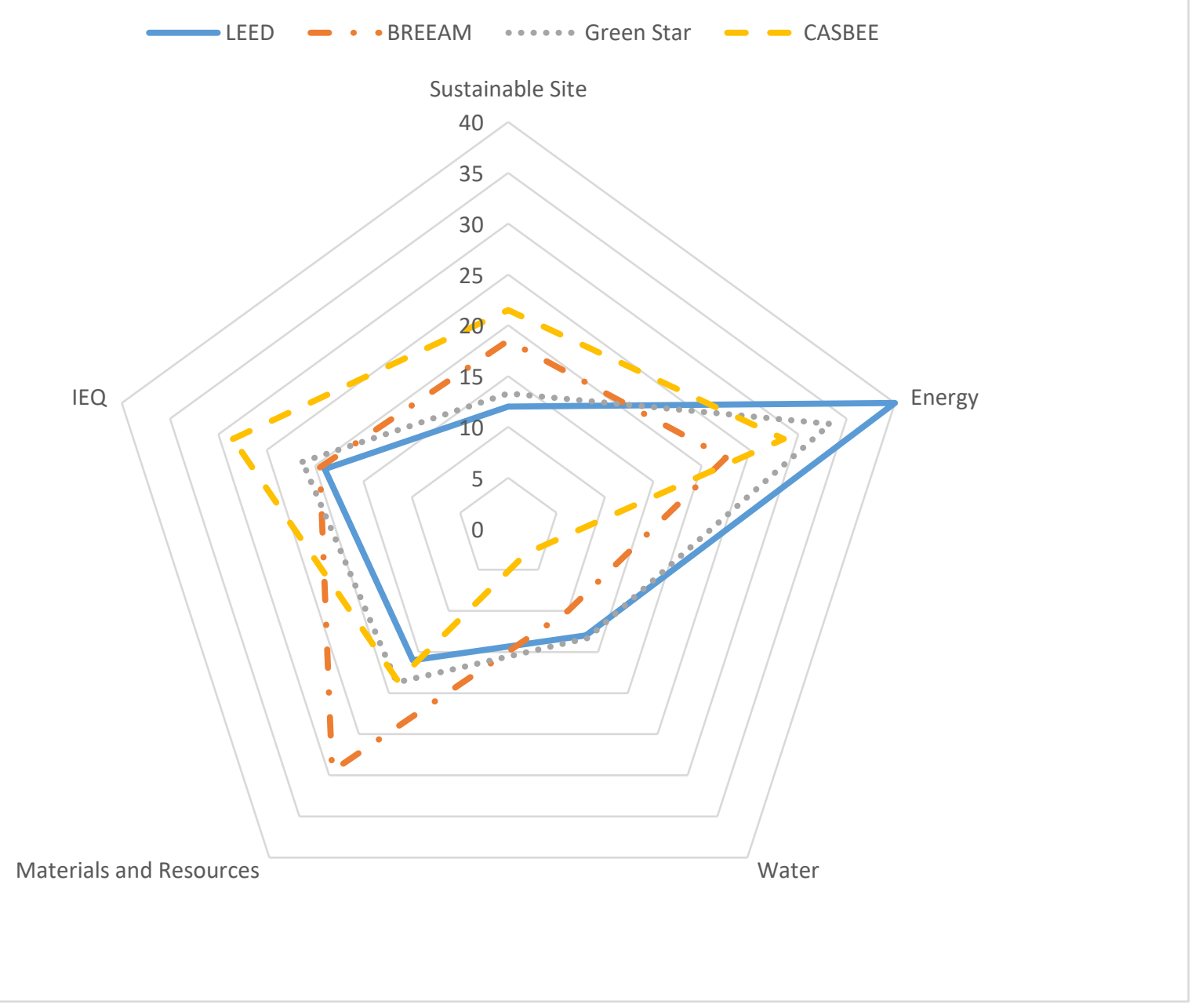

900 
901 Figure 2. Development methodology for Rapid Sustainability Assessment Method (RSAM)

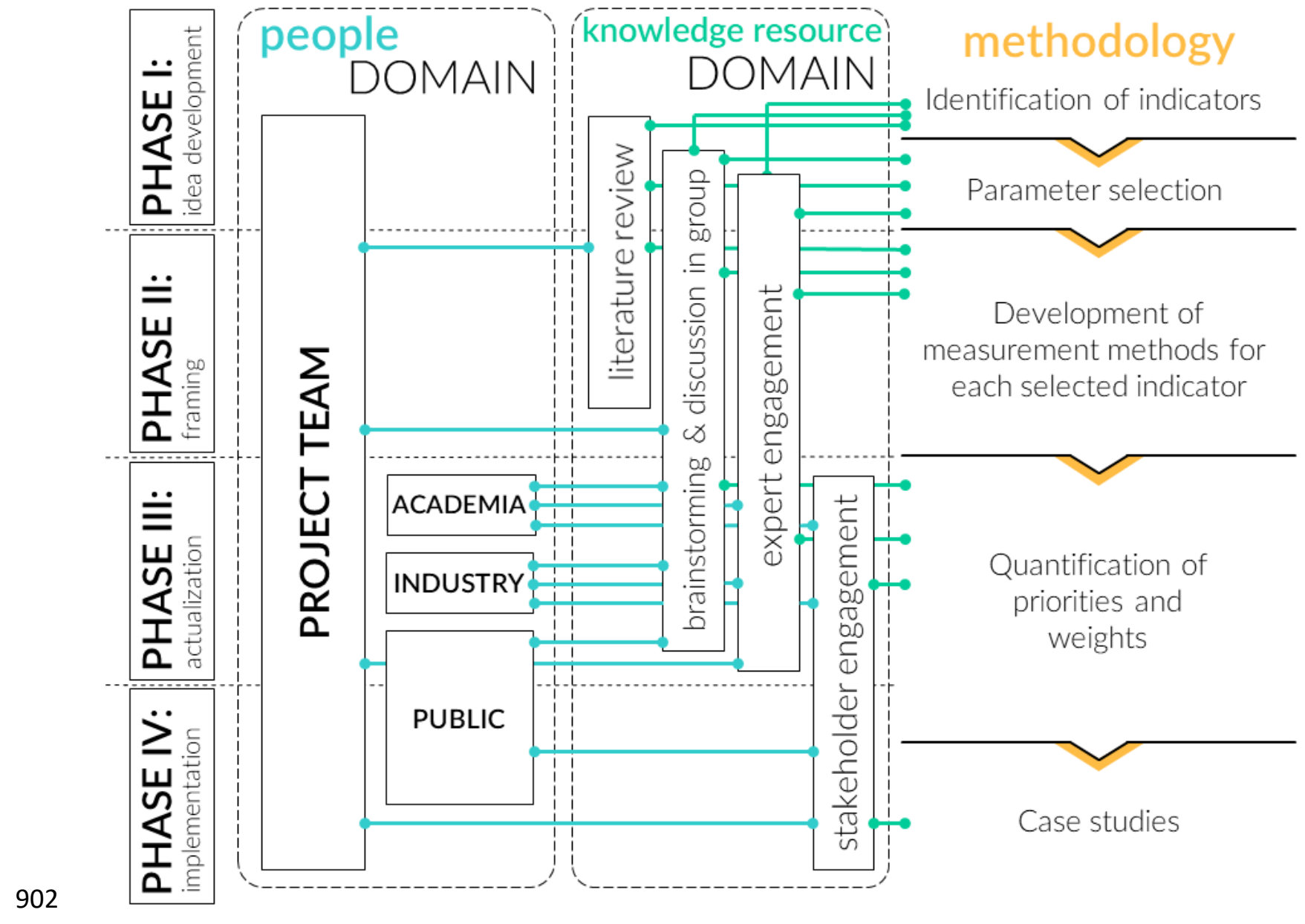

903 
904 Figure 3. Stakeholder groups' weights for Level 1 parameters

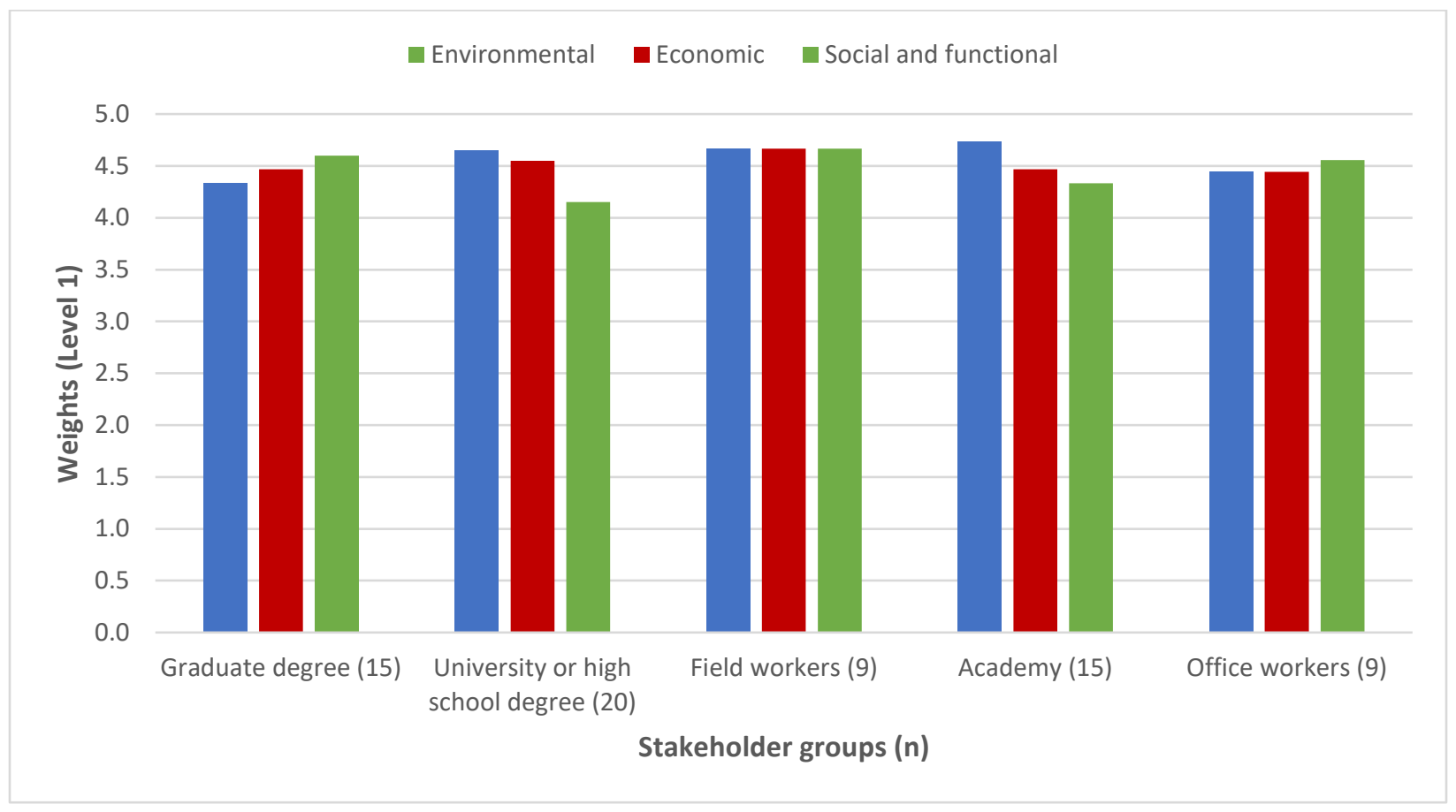

905

906 
907 Figure 4. Overall RSAM scores of all case studies

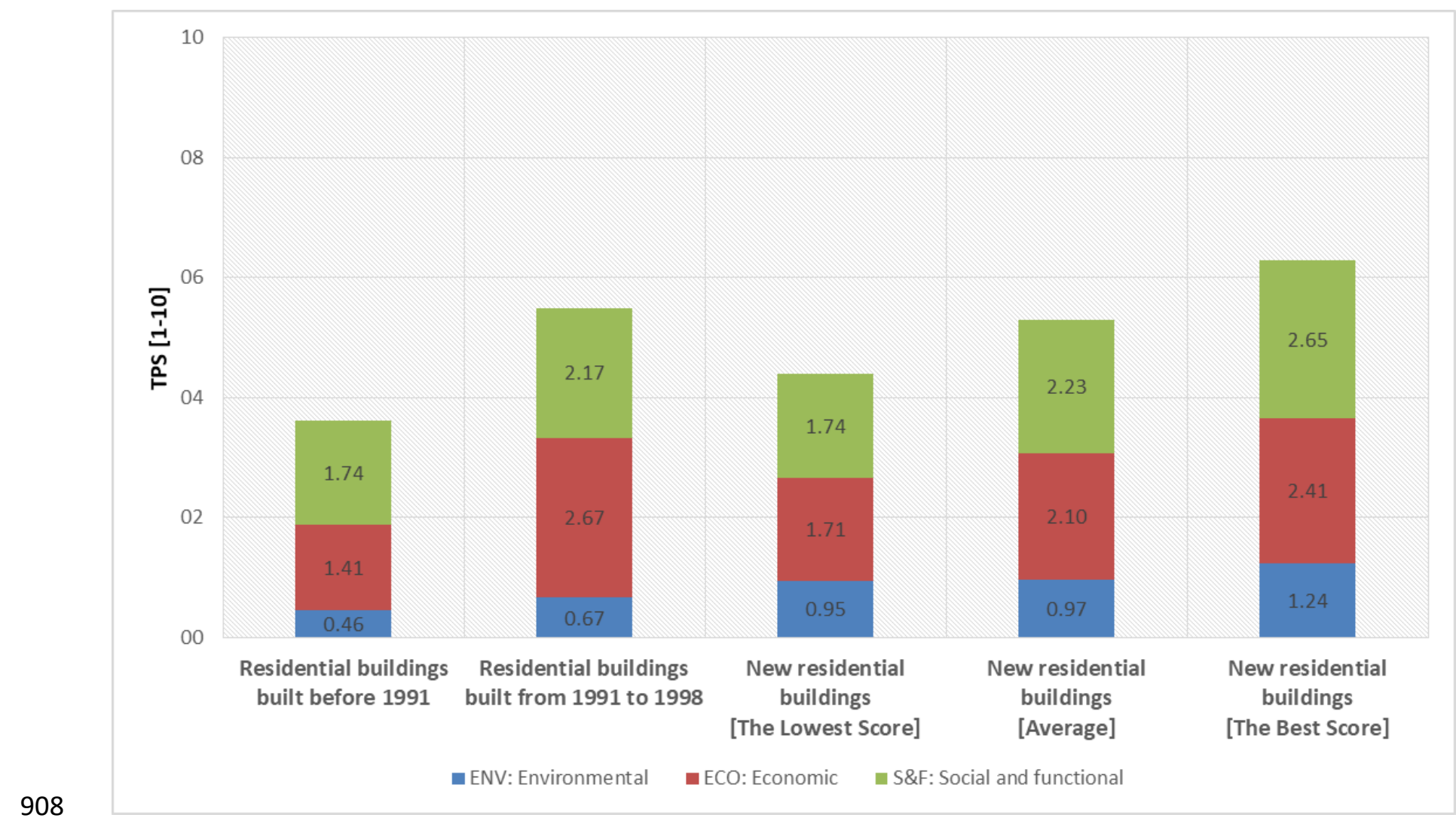

